\title{
風の強弱が高所と地面付近との気温差および 防霜ファンの効果に及ぼす影響
}

独立行政法人農業・食品産業技術総合研究機構野菜茶業研究所*

荒木环也・松尾喜義・深山大介・角川修

フルタ電機株式会社**

荒木慎介

(平成20年 7 月 8 日受理)

\section{Influence of Wind Velocity Fluctuation on Air Temperature Difference between the Fan and Ground Levels and the Effect of Frost Protective Fan Operation}

\author{
Takuya Araki, Kiyoshi Matsuo, Daisuke Miyama, Osamu Sumikawa \\ NNational Institute of Vegetable and Tea Science \\ National Agriculture and Food Research Organization \\ Shinsuke Araki \\ Fulta Electric Machinery Co., Ltd.
}

\section{Summary}

We invested the influence of wind velocity fluctuation on air temperature difference between the fan $(4.8 \mathrm{~m})$ and ground levels $(0.5 \mathrm{~m})$ and the effect of frost protective fan operation in order to develop a new method to reduce electricity consumption due to frost protective fan operation. The results of the investigations are summarized as follows:

(1) Air temperature difference between the fan $(4.8 \mathrm{~m})$ and ground levels $(0.5 \mathrm{~m})$ was decreased following an increase in wind velocity, and the difference was less than $1^{\circ} \mathrm{C}$ for a wind velocity more than $3.0 \mathrm{~m} / \mathrm{s}$ at a height of $6.5 \mathrm{~m}$.

(2) When the wind velocity was more than $2-3 \mathrm{~m} / \mathrm{s}$, there was hardly any increase in the temperature of the leaves. In contrast, when the wind velocity was less than $2-3 \mathrm{~m} / \mathrm{s}$, an increase in the temperature of the leaves was observed.

Based on these results, it is possible that when the wind velocity is greater than 2-3 $\mathrm{m}$, it prevents thermal inversion. Therefore, there would be no warmer air for the frost protective fan to return to the tea plants and the air turbulence produced by the frost protective fan would not

\footnotetext{
* $\quad$ 个428-8501 静岡県島田市金谷2769

** $=439-0002$ 静岡県菊川市倉沢1680-3
} 
reach the plants under the windy condition.

Key words:frost protection, frost protective fan, thermal inversion, wind velocity, tea plant キーワード：防霜，防霜ファン，逆転層，風速,茶樹

\section{1 目 的}

茶栽培において，一番茶生育期に発生する 晚霜による霜害は収穫期の遅れや減収を招き 経営的に大きな打撃を与えるため，十分な対 策が必要とされている。そのため茶園では防 霜ファンやスプリンクラーによる霜害防止対 策が施され，とりわけ防霜ファン（送風法） は全国で21,934haと広く利用されている 。

防霜法の一つである送風法は, 防霜ファン を地上 $5 \sim 10 \mathrm{~m}$ に設置して, 高所の比較的暖 かい空気と地面近くの冷たい空気を混合し, 放射冷却で冷えた作物体温を直接暖める方法

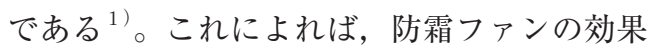
が見込める条件は，防霜ファンが設置されて いる $6 \sim 8 \mathrm{~m}$ の高所と茶株面との気温差があ る接地逆転が形成されている場合である。し かしながら実際の防霜ファンの制御は茶株面 付近の気温のみにより行われ，防霜ファンが 設置されている高所の気温が茶株面付近の気 温よりどの程度高いかについては考慮されて いない。また，茶園に吹く自然の風（以下、 自然風）が防霜ファンにより発生する風より も強い場合には，防霜ファンにより発生する 風の効果が見达めないと考えられる。これま で防霜ファンの効果については, 効果が見込 める条件下での観測事例について報告されて いる ${ }^{2 \sim 5)}$ 。しかし，上記のような自然風の ある条件下での防霜ファンの効果については 検討された例はない。仮に効果が認められな ければ，無駄な利用であり，利用法を再検討 する必要がある。

そこで本研究は, 防霜ファンの無駄な稼働 を排した節電型の制御法の開発を目標とし
て，風の強弱が高所と地面付近の気温差およ び防霜ファンの効果に及ぼす影響を明らかに する目的で実施した。

\section{2 方法}

2. 1 周辺の自然風の強弱が高所と地面付 近の気温の差に及ぼす影響

風向, 風速, 温度の計測には, 野菜茶業研 究所内 (静岡県島田市) の気象観測露場に設 置されている風向風速計と温度計（白金測温 体）を用いた。風速計は地上 $6.5 \mathrm{~m}$, 温度計 は放射除けのない状態で地上 $0.5 \mathrm{~m}$ およ゙゙ $4.8 \mathrm{~m}$ に設置した。風速は正時を含む前 10 分 間の平均值，温度は正時の瞬時值とした。 2006年 2 月 8 日19時から 2 月 14 日 6 時および 同年 3 月 2 日 19 時から 5 日 6 時の夜間の観測 データを利用した。この期間の昼間の天候は, おおむね晴れで, 研究所の気象観測装置の記 録では降水はなく, 日照時間は 2 月 8 日〜 2 月14日は8.4〜 10.3時間， 3 月 2 日〜 3 月 5 日 は7.7〜10.9時間だった。両期間とも初日（2 月 8 日，3月 2 日）が西高東低の冬型の気圧 配置で, 期間終盤に移動性高気圧に覆われて いた。

2. 2 周辺の自然風の強弱が防霜ファンの 効果に及ぼす影響

試験日時は2006年 2 月 12 日〜 13日および同 年 3 月 4 日〜 5 日の 18 時から翌朝 6 時にかけ て, 場所は野菜茶業研究所内の茶園で行った。 うね配置は南北方向, 樹高 $0.6 \mathrm{~m}$, うね幅 $1.8 \mathrm{~m}$, 樹形R3000の茶園の北端に防霜ファン を高さ $6.5 \mathrm{~m}$, 俯角 $30^{\circ}$ に設置し, 南方向に 防霜ファンを向けた。供試防霜ファンは 2 種 類の防霜ファンAおよびBで，Aは一般に利

社団法人日本茶業中央会：平成20年版茶関係資料, pp. 30 (2008). 
用されている首振りタイプ $(2.5 \mathrm{~kW}), \mathrm{B}$ 整 流格子を備えた風筒付きの首振り機構を持た ない 3 機のファン（側方 $1.5 \mathrm{~kW} \times 2+$ 中央 2 $\mathrm{kW} ）$ を 1 本の支柱に放射状に配置したタイ プである (写真)。供試ファンの稼動条件は, 60分間で 1 サイクルになるように, 防霜ファ ンA稼働, 停止, 防霜ファン B稼働, 停止を 15分間ずつ繰り返し, 夕方から朝にかけて連 続稼動させた。 2 機以外の周辺の防霜ファン には電力が供給されていなかった。

樹冠面の葉温は熱電対（T type）を葉裏 にテープで貼り付けて計測した。計測対象葉 はファン前方 $10 \mathrm{~m}$ の茶うね中央の表面にあ り, 葉柄が北に葉先が南に向いた地面に平行 な葉とした。ファンの設置高さの気温は，フ アン後方 $2 \mathrm{~m}$ に設置した熱電対（ $\mathrm{T}$ type）に より計測した。周辺の風速は, 防霜ファン設 置場所より北へ約 $95 \mathrm{~m}$ 離れた研究所内の気象 観測露場の風速データ（1 分間隔）を利用し た。計測した夜間はともに移動性高気圧に覆 われていた ${ }^{6)}$ (図1)。

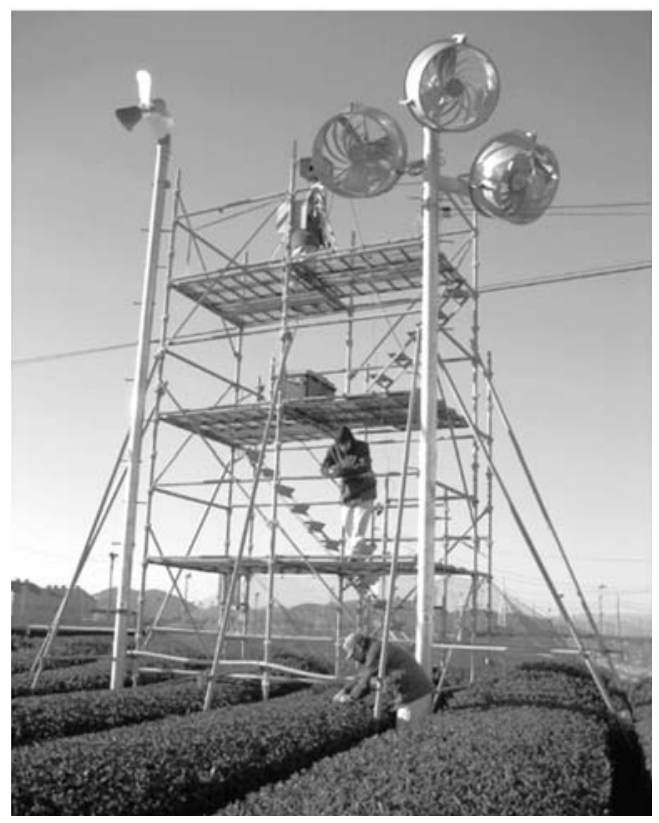

写真 供試防霜ファンと観測櫓 左：首振り右：多頭型

\section{3 結果および考察}

3. 1 周辺の自然風の強弱が高所と地面付 近の気温の差に及ぼす影響

図 2 に風速と地上 $4.8 \mathrm{~m}$ と $0.5 \mathrm{~m}$ との気温差 の関係を示した。気温差は最大 $4.1^{\circ} \mathrm{C}$, 最小 $0.3^{\circ} \mathrm{C}$ だった。風速の増加に伴い高所低所の 気温差は減少し, 平均風速が $3 \mathrm{~m} / \mathrm{s}$ 超える 状況では気温差が $1{ }^{\circ} \mathrm{C}$ 以下だった。

このことから, 平均風速がおよそ $3 \mathrm{~m} / \mathrm{s}$ を超えた場合には，茶園の空気はすでに攪拌 され接地逆転の形成が弱いか, あるいは形成 されていないと考えられる。これは，一般に 霜害が風のない夜に発生しやすいとされてい ることとも合致する。よってこのような条件 下では、防霜ファンの空気を混合する効果が 得られないと考えられる。

3. 2 周辺の自然風の強弱が防霜ファンの 効果に及ぼす影響

2006 年 2 月 12 日〜 13 日および同年 3 月 4 日 〜 5 日にかけての樹冠面葉温, 風速の変化を 図 3 に示した。

2 月 12 日〜 13 日の夜間の風向風速は 21 時頃 まで西南西の風, 約 $5 \mathrm{~m} / \mathrm{s}, 21$ 時〜 0 時頃ま で南西の風, 約 $3 \mathrm{~m} / \mathrm{s}, 0$ 時〜 4 時頃まで南 南西の風, 約 $2 \mathrm{~m} / \mathrm{s}$ 以下だった。葉温の変化 をみると 13 日 1 時から 5 時にかけての風が弱 い時間带は防霜ファンの稼働に対応した昇温 効果が認められたが，それ以外の時間帯では 防霜ファンが稼動しているにもかかわらず昇 温効果が認められなかった。

3 月 4 日〜 5 日の夜間の風速は 1 時頃まで 南西の風, 約 $2 \mathrm{~m} / \mathrm{s}$ 以下, 1 時〜 6 時頃まで 西南西の風， $2 \sim 3 \mathrm{~m} / \mathrm{s}$ 程度だった。葉温の 変化をみると 5 日 1 時までは防霜ファンの稼 働に対応した昇温効果がはっきりと認められ た。以後は 5 日 3 時台に風速が平均（60分間 平均) $2.4 \mathrm{~m} / \mathrm{s}$ （最小 $1.6 \sim$ 最大 $3.3 \mathrm{~m} / \mathrm{s}$ ） と風 がやや弱まった時に防霜ファンの稼働に対応 した昇温効果が若干認められたが，それ以外 


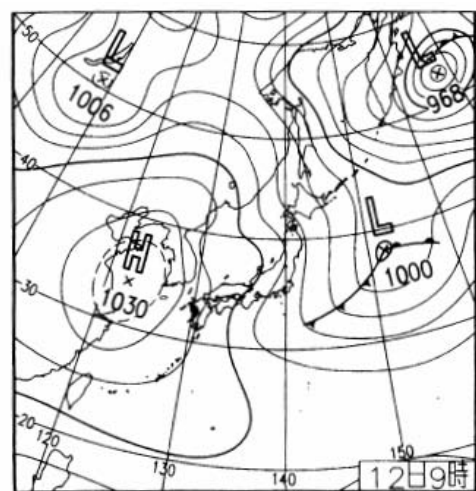

2006年2月12日09:00

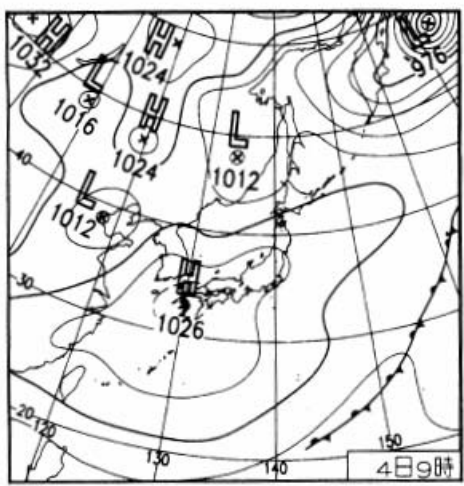

2006年3月4日09:00
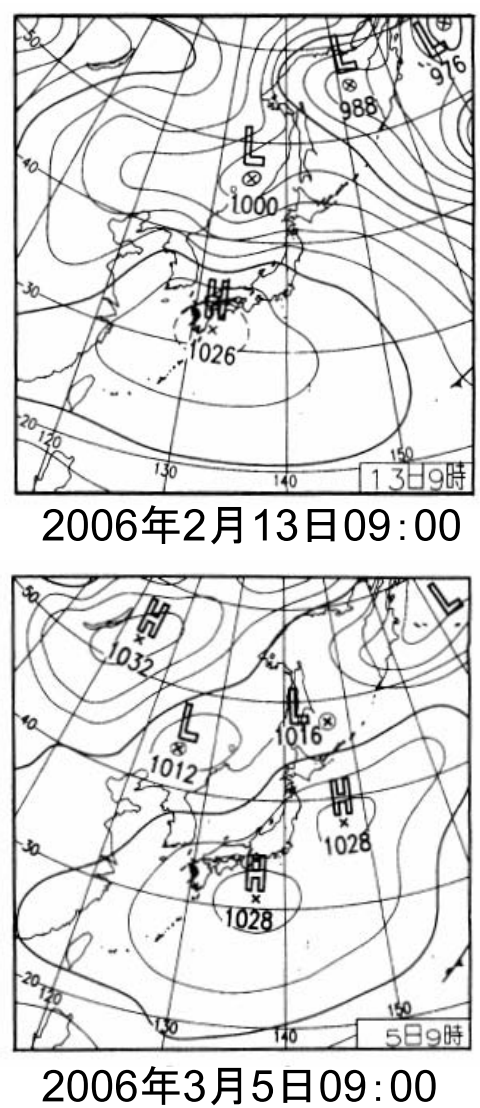

図 1 観測夜前後の天気図 ${ }^{6)}$

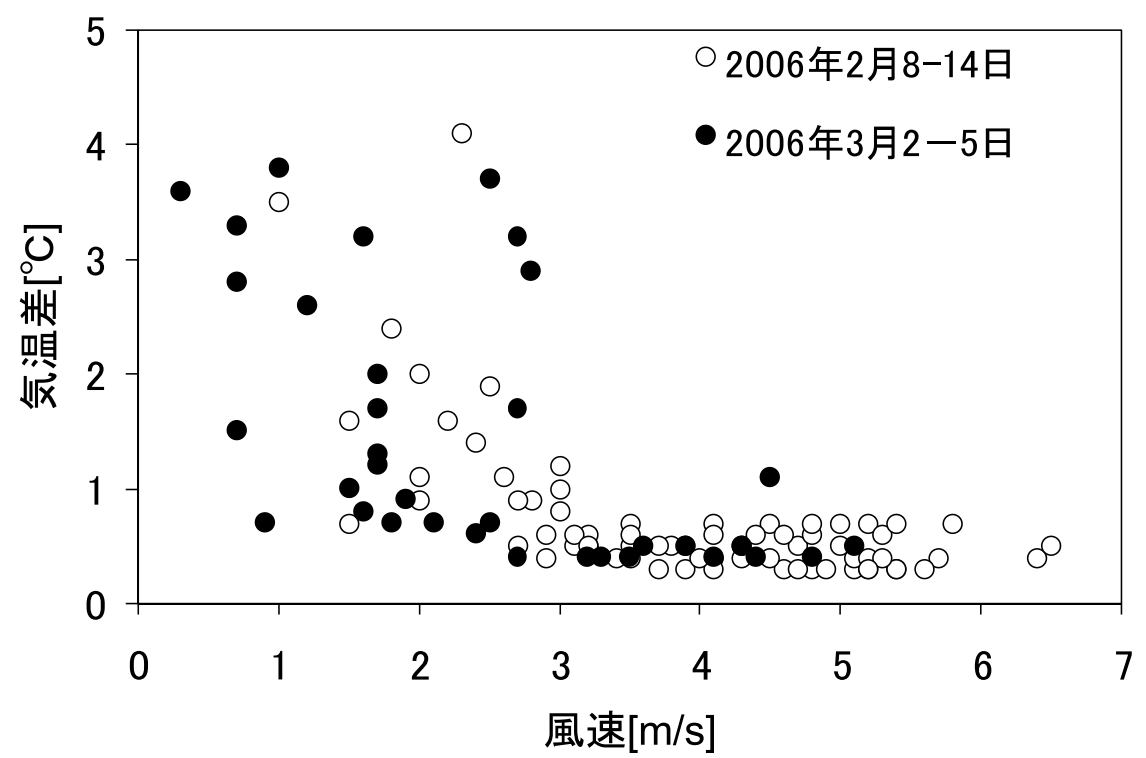

図 2 風速が地上0.5mと4.8mとの気温差におよぼす影響 

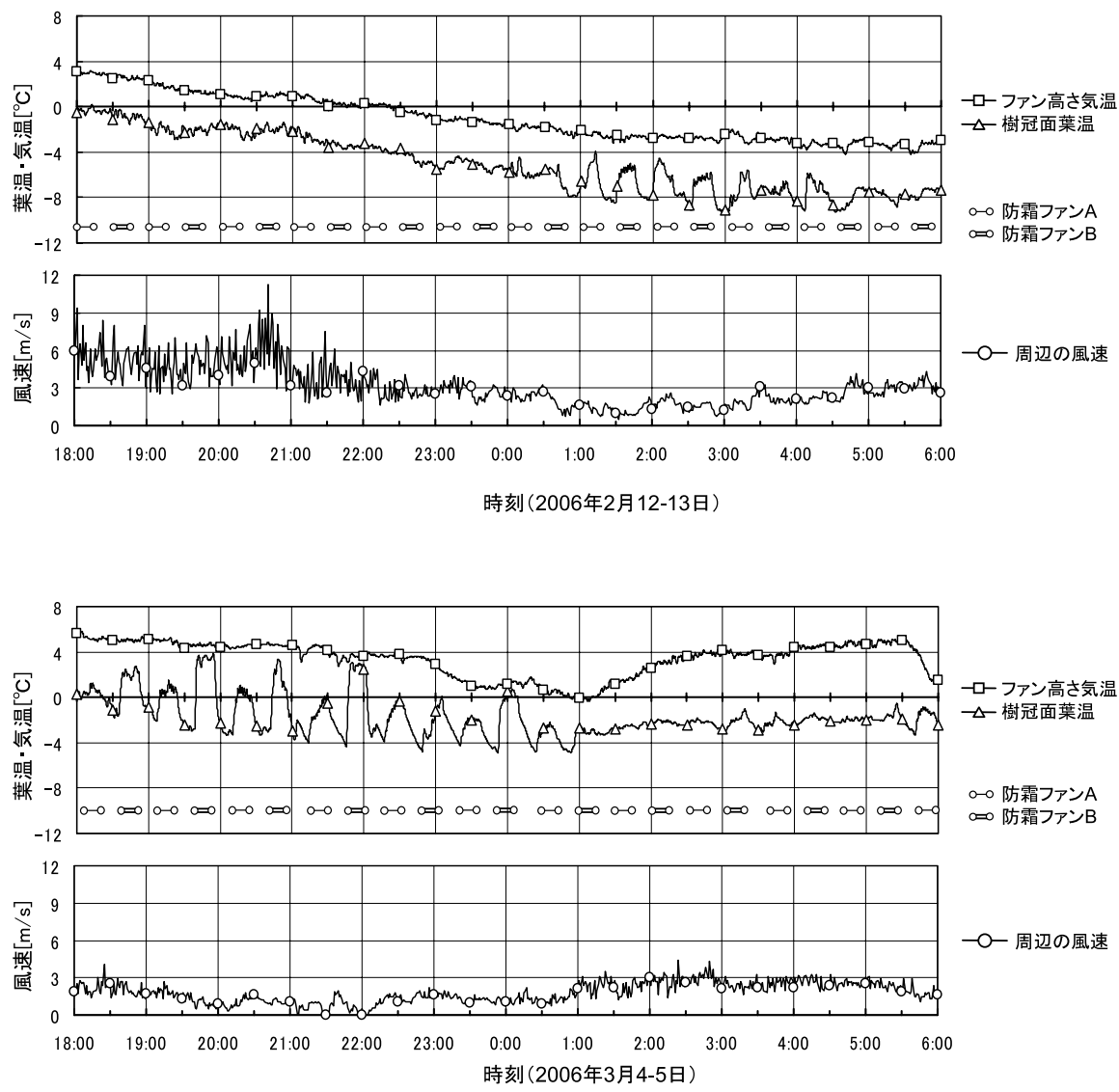

図 3 防霜ファンの稼働による樹冠面葉温の変化と観測時の風速

の時間帯では，認められなかった。

2 月 13 日の 0 時〜 4 時頃と 3 月 5 日の 1 時 〜 6 時頃は, ともに南向きに設定された防霜 ファンとはほほ対向する南から西の風で，2 月 13 日は風速約 $2 \mathrm{~m} / \mathrm{s}$ 以下, 3 月 5 日は 2 $3 \mathrm{~m} / \mathrm{s}$ 程度であった。風速の小さい 2 月 13 日 は防霜ファンの稼働に対応した昇温効果が認 められたが, 風速が若干大きい3月 5 日は認 められなかった。

観測回数が不十分であるが二晚の観測で は, 自然風が風速 $2 \sim 3 \mathrm{~m} / \mathrm{s}$ 程度以上あるよ うな場合, 防霜ファンの稼働に対応した昇温 効果が認められなかった。このことは, 防霜 ファンにより発生した風が自然風により乱さ れ茶株面まで到達していない可能性や, 試験
3.1 の結果にみられるように高所低所の気温 差が小さいために葉温計測において防霜ファ ンの稼働に対応した昇温効果が得られなかっ たと考えられる。

3 . 3 節電型制御の可能性

以上の結果から, 自然風が風速 $2 \sim 3 \mathrm{~m} / \mathrm{s}$ 程度以上あるような場合, 高所低所の気温差 が小さいために作物体温を直接暖める効果が 小さい可能性や防霜ファンにより発生した風 が自然風により乱され茶株面まで到達してい ない可能性が考えられる。

このような気温差や風速条件をセンサなど で検出し，防霜ファンの稼働制御に利用すれ ば，効果が期待できないような環境下での無 駄な稼働をなくした節電型の制御が可能にな 
ると考えられる。今回は防霜期間に調查して いないことから，実際の霜害防止効果や節電 効果については今後検討する必要がある。

\section{4 摘 要}

防霜ファンの無駄な稼働を排した節電型の 制御法の開発を目的として, 茶園の風の強弱 が高所と地面付近との気温差および防霜ファ ンの効果に及ぼす影響について調査した結果 以下の点が明らかになった。

1 ）気象観測露場における観測から, 地上 $6.5 \mathrm{~m}$ の風速の増加に伴い, 高所 $(4.8 \mathrm{~m})$ と低所 $(0.5 \mathrm{~m})$ の気温差は減少し, 平 均風速が $3 \mathrm{~m} / \mathrm{s}$ を超える状況下では気温 差が $1{ }^{\circ} \mathrm{C}$ 以下だった。

2 ）風速 $2 \sim 3 \mathrm{~m} / \mathrm{s}$ 程度以上の状況下では, 防霜ファンの稼働に対応した樹冠面葉温 の昇温効果が認められなかったが、風速 がそれ以下の場合ははっきりと認められ た。

以上の結果より, 気温差や風速条件を防霜 ファンの稼働制御に利用すれば，効果が期待 できないような環境下での無駄な稼働をなく した節電型の制御が可能になると考えられ た。

\section{謝辞}

本研究は野菜茶業研究所とフルタ電機株式 会社との協定研究「多頭型防霜ファンが茶園 環境に及ぼす影響の解析」および農林水産省
委託プロジェクト研究「地球温暖化が農林水 産業に及ぼす影響評価と緩和及び適応技術の 開発」の一部として実施したものである。こ こに記して，関係各位に謝意を表する。

\section{引用文 献}

1 ) 日本農業気象学会 (1997)：農業気象用語 解説集. 農業気象学会, 東京, 157.

2 ) 高橋恒二 - 青野英也 - 田中静夫 - 築瀬好 充 (1958)：茶樹の凍霜害防除に関する研 究 (第 2 報)。送風法による茶樹の凍霜 害防除について。日本作物学会紀事, No27 (1)， 135-136.

3 ）高橋恒二・青野英也・田中静夫 - 築瀬好 充・吉川 茂(1961)：茶樹の凍霜害に関 する研究. 降霜時の微細気象と凍霜害の 応急的ならびに栽培的防止法の研究. 東 海近畿農業試験場報告, 茶業部, No8, 30-162.

4 ）此本晴夫 ·鈴木幸隆・木村政美 - 岩崎正 男・木村 進・小野循男 (1976) : 茶園に おける小型送風機の防霜効果. 静岡県茶 業試験場研究報告, No7, 43-57.

5 ) 常包一明 - 矢野 清 - 安部秀雄 (1985)： 仲南町中山地区傾斜地茶園における防霜 ファンの効果. 香川県農業試験場研究報 告, No37, 7-17.

6 ) 気象庁 (2007)：2007年版気象年鑑. 気象 業務支援センター，東京，10-13. 